
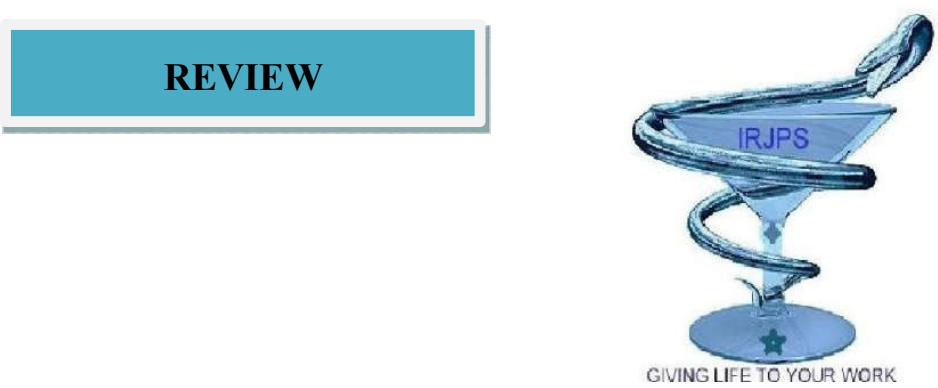

\title{
NEUROTOXICITY AND CRIMINAL BEHAVIOR
}

\author{
Ahed J Alkhatib*, Nayef Alzamel \\ Department of Legal Medicine, Toxicology of Forensic Medicine, School of Medicine, Jordan University of Science \\ and Technology, Jordan
}

\section{Submitted on: 23.04.18; $\quad$ Revised on: 19.05.18; $\quad$ Accepted on: 29.05.18}

\begin{abstract}
:
Criminal behaviors have become a phenomenon that disturbs the communities. The objective of this study is to review the literature about neurotoxicity and criminal behavior.Criminalbehavior implies the use of violence against others. We think that the theories explaining criminal behaviors have their limitations because they put focus mainly on social aspects. From our findings and others, we have reached to some assumptions that neurotoxicity induces changes in brain chemistry that, in turn, changes the perception and lowers the tolerance to external violent stimuli leading to criminal behaviors. In this study, we put focus on the exposure to heavy metals such as lead (pb) due to their impact on nervous system. We have shown the experience of authors in this aspect and how the prevalence of crime is associated with the wide spread of lead $(\mathrm{pb})$.As a conclusion, we think that the environmental theory of violent actions can explain the increasing trend of crime and violence.
\end{abstract}

KEYWORDS: Neurotoxicity, Crime, Violence, Behavior, Lead (pb), Environment.

Corresponding author: Ahed J Alkhatib

E-mail: ajalkhatib@just.edu.jo

Mobile: 00962795905145
Indian Research Journal of Pharmacy and Science; 17(2018)1432-1438;

Journal Home Page: https://www.irjps.in

DOI: 10.21276/irjps.2018.5.2.5 


\section{INTRODUCTION:}

\section{Harmful impacts of toxins on brain chemistry}

The idea of having harmful effects of toxins on brain chemistry and behavior has gained much attention (Gottschalk et al., 1991; Masters, 2018). A good illustrating example is the exposure to lead $(\mathrm{Pb})$ that decreases intelligence and learning ability (Alkhatib et al., 2013).

Scientistshave found an association between lead concentration and each of poor impulse control, learning disabilities, and violence (Needleman andGatsonis, 1991; Cory-Slechta, 1995).

\section{Brain chemistry, environmental toxins, and} violent crime

According to Lee (2000), it is not highly acceptable the idea of linking brain chemistry and violent crime to some social scientists, but actually an emerging evidence in which lowering the exposure to toxins can lowercrime rates is provided by the Congressional ban on the sale of leaded gasoline.

\section{Lead neurotoxicity}

Lead has high affinity for metal-binding sites that implies the presences of lead ability to interfere with cellular physiology (Canfield et al., 2003; Lidskyand Schneider, 2003; Garza et al., 2006). According to the Center for Disease Control (CDC, 1991), a blood lead level of $10 \mu \mathrm{g} / \mathrm{dLwas}$ considered as the lower level of medical concern. This level was also recommended by world health organization (Tong et al., 2000). Several studies targeting children have indicated to the existence of irreversible neurological problems at lower concentrations $<10 \mu \mathrm{g} / \mathrm{dl}$. These studies showed depending on cellular and molecular evidence that lead toxicity has no threshold (Needleman et al., 190;Bellinger et al., 1992;Czerwionka-Szafl and Nowak, 1996;Canfield et al., 2003;Lidsky et al., 2003).

From a pathophysiological point of view, studies showed difficulties in the management and removal of lead effectively which makes its accumulation in the body (Garza et al., 2006). Lead has a long halflife ranging from 35 days in blood, 2 years in the brain, and decades in bone. It is expected that such long-term deposits can increase systemic lead levels in cases of pregnancy, a matter with impacts on fetus (Agency for Toxic Substances and Disease Registry,
1999;Konecki et al., 2000;Lidskyand Schneider, 2003).

Nervous system is mostly impacted by lead, particularly in the period of development (Garza et al., 2006). According to this context, we can understand the reasons making damage in children by lead poisoning more dangerous than that of adults, through the induction of alterations in their motor and cognitive abilities (Needleman et al., 1990; CDC, 1991; Bellinger et al., 1992; Canfield et al., 2003).

Several studies have reported various alterations to be associated with blood lead levels $<9 \mu \mathrm{g} / \mathrm{dL}$ including reading disorders, dyscalculia, deficits in short-term memory, and visual agnosia (Bellingeret al., 1992; Dietrich et al., 1993; Stiles and Bellinger, 1993; Walkowiak et al., 1998;Klaassen, 2001; Lidsky and Schneider, 2003).

It is worth noting that the impacts of lead intoxication exceed the cognitive impairments and lowered scores of intelligence tests to the degree of assessment of the damage at low-level intoxication (Lidsky and Schneider, 2003).The study of Wakefield (2002) introduced the social dimension to lead intoxication through linking the lead exposure with behavioral disorders. Other studies found a correlation between lead levels and the crime rate. Further, lead intoxication was a significant predictor for the criminal behavior (Needleman et al., 1996; Dietrich et al., 2001; Streteskyand Lynch, 2001; Wakefield et al., 2002). In their study, Opler et al (2004) reported a correlation between lead intoxication and schizophrenia. Several studies have reported impairments in sensory systems such as vision, hearing, and balance deficiencies with persons with lead intoxication (Bhattacharya et al., 1990, 1995; He et al., 2000; Mameliet al., 2001; Counter and Buchanan, 2002; Garza, 2004).

It has been indicated by other studies that balance loss resulting from vestibular malfunctioning can be explained by the high sensitivity of this system to lead (Bhattacharya et al., 1993; Mameli et al., 2001). There are several mechanisms responsible for the impacts of the exposure to lead in terms of damage or functional alteration on nervous system. These mechanisms include (Lidskyand Schneider, 2003):

- $\quad$ Lipid peroxidation.

- Excitotoxicity.

- Alterations in neurotransmitter synthesis.

- Storageand release. 
- Alterationsin the expression and operation of receptors.

- Interferencewith mitochondrial metabolism.

- Interferencewith second-messenger systems, and

- Damageto the astroglia and oligodendroglia. According to Agency for Toxic Substances and Disease Registry (1999), the exposure to lead impacts all tissues and more impacts have been reported on the central nervous system, particularly, the hippocampus.

If we want to go in deep details in studying possible links between environmental pollution and crime, we have to make a focus on biochemical toxins that affect both of structure and function of brain taking into consideration the complicated interactions with diet, alcohol or drug use, stress, and other ecological or cultural factors (Masters, 2018). According to this context, neurotoxicity is one of the causes including poverty, individual character, and other social factors that increases crime rates (Masters, 2018).

Lead has the ability to interfere with various functions in the body and it is considered toxic to many organs including the heart, bones, intestines, kidneys, blood, and reproductive system (Tong et al. 2000). The impacts of exposure to lead are more likely to affect the brain and central nervous system (Tong et al. 2000) even at much lower levels than the accepted $10 \mu \mathrm{g} / \mathrm{dL}$ (Lanphear et al. 2000).

At severe cases, lead exposure may cause coma, seizures, stroke and even death. The exposure to lead is a problem at any time, the most severe effects have been observed in children (Fordyce, 2012). Children are more likely to be affected by lead exposure because of rapid mental/neural development at this age and the exposure to lead is likely to affect this development (Winneke, 2011). Unfortunately, lead exposure effects on children are irreversible, and it is important to study the exact effects of lead exposure on children's mental development.

\section{The impact of lead exposure on neuro- developmental disorders in children}

The most observable effects of lead exposure on children are neurological in nature compared with adults (Leggett, 1993; Cory-Schlecta and Schaumburg, 2000). The lead intake can reach the brain of children (Lidsky, 2002). However, lead is considered as a potent neurotoxin (Winneke, 2011), and children are affected by lead even at low concentrations (Lidsky, 2002).

Among young adults, it was found that increased blood lead levels were significantly associated with increased risk of major depressive disorder compared with individuals who had a blood lead level $<0.7$ $\mu \mathrm{g} / \mathrm{dL}$ (Bouchard et al., 2009). This trend of having environmental lead exposure to be associated with depression is not well established among studies. In their study, Golub et al (2009) did not find this association.

Sleeping disturbances among children with lead exposure have been reported in several studies (Needleman, 1996; Owens-Stively, 1997; Kordas et al., 2010). Other studies confirmed this finding in adolescents (Olimpio, 2010).

\section{The impact of lead exposure onsocial problems}

Several authors investigated the relationship between lead exposure and social problems. An association between lead exposure and social problems has been reported in children and adolescents (Roy, 2009; Olympio, 2010).

Several studies have found positive relationships between lead exposure in children and attention problems including ADHD, inattention, and distractibility (Needleman, 1979; Yule, 1984; Thomson, 1989; Bellinger, 1994; Wang, 2008; Nigg, 2010; Nicolescu, 2010).

It has been found that there is a positive relationship between lead exposure and antisocial or delinquent behaviorin childhood and adolescence(Needleman, 1996; Dietrich, 2001). Denno (1990) conducted a survey of Philadelphia youths and reported that a previous history of lead poisoning as a significant predictor of criminality in males (Denno, 1990).

\section{CONCLUSION:}

The present study showed that neurotoxicity resulting from exposure to heavy metals is a significant predictor of criminal behavior, particularly if the exposure to heavy metals occurred in childhood. 


\section{REFERENCES}

1. Agency for Toxic Substances and Disease Registry (1999). Toxicological profile for lead. US Department of Health and Human Services, Public Health Service.

2. Ahed J. Al Khatib, Haitham M. Taani, Mohammed Al Asseiri, A'aesha M. Qasem, ManalKassab, Fatima Laiche (2013). Hematological changes in prisoners with higher blood lead levels compared with general population. European Scientific Journal, 9:1857-7881.

3. Aníbal Garza, Rosario Vega, Enrique Soto (2006). Cellular mechanisms of lead neurotoxicity. Med SciMonit, 2006; 12(3): RA57-65.

4. Bellinger DC (2004). Lead. Pediatrics, 113: 1016-22 75.

5. Bellinger DC, Stiles KM, Needleman HL (1992). Low-level lead exposure, intelligence and academic achievement: a long-term follow-up study. Pediatrics, 90: $855-61$.

6. Bhattacharya A, Shukla R, Bornschein RL et al (1990). Lead effects on postural balance of children. Environ Health Perspect, 89: $35-42$.

7. Bhattacharya A, Shukla R, Dietrich K et al (1995). Effect of early lead exposure on children's postural balance.Dev Med Child Neurol, 37: 861-78.

8. Bhattacharya A, Shukla R, Dietrich KN et al (1993). Functional implications of postural disequilibrium due to lead exposure.Neurotoxicology, 14: 179-89

9. Bouchard MF, Bellinger DC, Weuve J, Matthews-Bellinger J, Gilman SE, Wright RO, Schwartz J, Weisskopf MG (2009). Blood Lead Levels and major depressive disorder, panic disorder, and generalized anxiety disorder in US young adults. Archive of General Psychiatry, 66:1313-9.

10. Canfield RL, Henderson CR, Cory-Slechta DA et al (2003). Intellectual impairment in children with blood lead concentrations below 10 microg per deciliter. $\mathrm{N}$ Engl $\mathrm{J}$ Med, 348: 1517-26.

11. CDC (1991). Preventing Lead Poisoning in Young Children. U.S. Department of Health and Human Services, Public Health Service.

12. Cory-Schlecta, D., \& Schaumburg, H. (2000). Lead, inorganic.In P. Spencer, H. Schaumburg, \& A. Ludolph (Eds.), Experimental and clinical neurotoxicology (2nd ed., pp. 708-720). New York: Oxford University Press.

13. Cory-Slechta DA (1995). Relationships between Lead Induced Learning Impairments and Change in Dopaminergic, Cholinergic, Glutamatergic Neurotransmitter System Functioning. Annual Review of Pharm Toxic 35: 3337-395.

14. Counter SA, Buchanan LH (2002). Neuroototoxicity in Andean adults with chronic lead and noise exposure. J Occup Environ Med, 44: 30-38.

15. Czerwionka-Szaflarska M, Nowak A (1996). Lead microintoxication and intellectual development in children. Med SciMonit, 2(5): 695-99.

16. Denno, D.W (1990). Biology and Violence. New York, NY: Cambridge University Press, 1990.

17. Dietrich KN, Berger OG, Succop PA et al (1993). The developmental consequences of low to moderate prenatal and postnatal lead exposure: intellectual attainment in the Cincinnati Lead Study Cohort following school entry. NeurotoxicolTeratol, 15: 3744. 
18. Dietrich KN, Ris MD, Succop PA et al (2001). Early exposure to lead and juvenile delinquency.NeurotoxicolTeratol, 23: 51118.

19. Fordyce, Fiona Farrar (2012). Neurotoxic Effects Of Childhood And Adolescent Blood Lead Levels. Public Health Theses. 1092. http://elischolar.library.yale.edu/ysphtdl/109 $\underline{2}$

20. Garza CA (2004). Efectos del plomosobre la transmisiónsináptica y la actividadaferente en el sistema vestibular (Biomedicine Degree Thesis).Facultad de Medicina, Universidad Autónoma de Puebla.

21. Golub, Natalia I, Paul C. Winters and Edwin van Wijngaarden (2009). A Population based study of blood lead levels in relation to depression in the United States. International Archives of Occupational and Environmental Health, 83: 771-777.

22. Gottschalk L, Rebello T, Buchsbaum MS, Tucker HG, Hodges HL (1991). Abnormalities in trace elements as indicators of aberrant behavior. Comprehensive Psychiatry 32(3): 229-37.

23. He L, Poblenz AT, Medrano CJ, Fox DA (2000). Lead and calcium produce rod photoreceptor cell apoptosis by opening the mitochondrial permeability transition pore. $\mathrm{J}$ BiolChem, 275: 12175-84.

24. Kitman Jamie Lee (2000) The Secret History of Lead (use of leaded gasoline). The Nation.

25. Klaassen CD (2001).Heavy metals and heavy-metal antagonists. In: Hardman JG, Limbird LE, Gilman AG (eds.). The Pharmacological Basis of Therapeutics. 10 ed. New York: McGraw Hill, 1851-75.

26. Konecki J, Błażejowski J, Słowiński J, Helewski K (2000). Influence of chronic cadmium exposure during pregnancy on
DNA synthesis in different organs of rat offspring. Med SciMonit, 6(6): 1077-81.

27. Kordas K, Queirolo EI, Ettinger AS, Wright RO, Stoltzfus RJ (2010). Prevalence and Predictors of Exposure to Multiple Metals in Preschool Children from Montevideo, Uruguay." Science of the Total Environment, 408:4488-94.

28. Lanphear, BP, Dietrich K, Auinger P, Cox C (2000). Cognitive Deficits Associated with Blood Lead Concentrations $<10$ micrograms/dL in US Children and Adolescents.Public Health Rep. 115:521529 .

29. Leggett, R. (1993). An age-specific kinetic model of lead metabolism in humans. Environmental Health Perspectives, 101, 598-616.

30. Lidsky TI, Schneider JS (2003). Lead neurotoxicity in children: basic mechanisms and clinical correlates. Brain, 126: 5-19.

31. Lidsky, Theodore I., and Jay S. Schneider (2002). Lead Neurotoxicity in Children: Basic Mechanisms and Clinical Correlates. Brain: A Journal of Neurology. 126:5-19.

32. Mameli O, Caria MA, Melis $F$ et al (2001).Neurotoxic effect of lead at low concentrations. Brain Res Bull, 55: 269-75.

33. Needleman HL, Gatsonis B (1991). Metaanalysis of 24 studies of learning disabilities due to lead poisoning. JAMA 265: 673-678.

34. Needleman HL, Gunnoe C, Leviton A, Reed R, Peresie H, Maher C, Barrett P (1979). Deficits in psychologic and classroom performance of children with elevated dentine lead levels. New England Journal of Medicine, 300:689-695.

35. Needleman HL, Riess JA, Tobin MJ et al (1996). Bone lead levels and delinquent behavior. JAMA, 275: 363-69. 
36. Needleman HL, Schell A, Bellinger D et al (1990). The long-term effects of exposure to low doses of lead in childhood. An 11-year follow-up report. N Engl J Med, 322: 83-88.

37. Needleman, HL, Riess, JA, Tobin, MJ, Biesecker, GE, Gerrnhouse, JB (1996). Bone Lead Levels and Delinquent Behavior. Journal of the American Medical Association, 275: 363-9.

38. Nicolescu R, Petcu C, Cordeanu A, Fabritius K, Schlumpf M, Krebs R, Kramer U, Winneke G (2010). Environmental exposure to lead, but not other neurotoxic metals, relates to core elements of ADHD in Romanian children: Performance and questionnaire data." Environmental Research, 110:476-483.

39. Nigg JT, Nikolas M, Knottnerus GM, Cavanagh K, Friderici K (2010). Confirmation and extension of association of blood lead with attentiondeficit/hyperactivity disorder (ADHD) and ADHD symptom domains at populationtypical exposure levels. " Journal of Child Psychology and Psychiatry, 51:58-65.

40. Olympio, KP, Oliveira PV, Naozuka J, Cardoso MR, Marques AF, Gunther WM, Bechara EJ (2010). Surface Dental Enamel Lead Levels and Antisocial Behavior in Brazilian Adolescents. Neurotoxicology and Teratology, 32:273-9.

41. Opler MG, Brown AS, Graziano $J$ et al (2004). Prenatal lead exposure, deltaaminolevulinic acid, and schizophrenia. Environ Health Perspect, 112: 548-52.

42. Owens-Stively J, Spirito A, Arrigan M, Alario A (1997). Elevated lead levels and sleep disturbance in young children: preliminary findings." Ambulatory ChildHealth. 2:221-229.

43. Roger D Masters (2018). Neurotoxicity and Violent Crime: Linking Brain Biochemistry,
Toxins, and Violent Crime. MedCrave Group LLC, January, 24.

44. Roy A, Bellinger $\mathrm{D}, \mathrm{Hu} \mathrm{H}$, Schwartz J, Ettinger AS, Wright RO, Bouchard $\mathrm{M}$, PalaniappanK, Balakrishnan K (2009). Lead Exposure and Behavior Among Young Children in Chennai, India. Environmental Health Perspectives, 117:1607-11.

45. Stiles KM, Bellinger DC (1993). Neuropsychological correlates of low-level lead exposure in school-age children: a prospective study. NeurotoxicolTeratol, 15: 27-35 79 .

46. Stretesky PB, Lynch MJ (2001): The relationship between lead exposure and homicide. Arch PediatrAdolesc Med, 155: 579-82.

47. Thomson GO, Raab GM, Hepburn WS, Hunter R, Fulton M, Laxen DP (1989). Blood-lead levels and children's behaviour-results from the Edinburgh Lead Study." Journal of Child Psychology and Psychiatry, 30:515-528.

48. Tong S, von Schirnding YE, Prapamontol T (2000). Environmental lead exposure: a public health problem of global dimensions. Bull World Health Organ, 78: 1068-77.

49. Wakefield J (2002). The lead effect? Environ Health Perspect, 110: A574-A580.

50. Walkowiak J, Altmann L, Kramer U et al (1998). Cognitive and sensorimotor functions in 6-year-old children in relation to lead and mercury levels: adjustment for intelligence and contrast sensitivity in computerized testing. NeurotoxicolTeratol, 20: 511-21.

51. Wang HL, Chen XT, Yang B, Ma FL, Wang S, Tang ML, Hao MG, Ruan DY (2008). Case-control study of blood lead levels and attention deficit hyperactivity disorder in 
Chinese children. Environmental Health Perspectives, 116:1401-1406.

52. Winneke, G (2011). Developmental Aspects of Environmental Neurotoxicity: Lessons from Lead and Polychlorinated buphenyls. Journal of Neurological Science, 308:9-15.
53. Yule W, Urbanowicz MA, Lansdown R, Millar I (1984). Teachers' ratings of children's behaviour in relation to blood lead levels. British Journal of Developmental Psychology. 2:295-305. 